
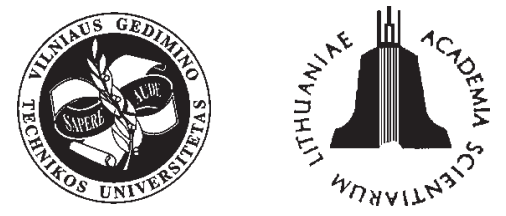

ISSN $1392-3730$

JOURNAL OF CIVIL ENGINEERING AND MANAGEMENT

http:/www.jcem.vgtu.lt

2005, Vol XI, No 3, 163-168

\title{
ACCOUNTING FOR EFFECTS OF DECREASING BOND BETWEEN CONCRETE AND REBARS ON SEISMIC RESISTANCE OF REINFORCED CONCRETE STRUCTURAL ELEMENTS
}

\author{
Andrey V. Benin \\ Petersburg State Transport University, Moskovskiy pr. 9, 190031 St. Petersburg, Russia \\ E-mail:pmik@cards.lanck.net
}

Received 13 Jan 2005; accepted 20 June 2005

\begin{abstract}
This study reviews an alternative of reinforced concrete finite element model as a system, where physical conditions for system components are recorded independently and, in addition, conditions for interaction of system components on their contact are also introduced. In this case, we are able to take into account all specific features of reinforcement, to trace the history of loading and destruction for each rebar. Basic specific feature of reviewed problem ascertains the necessity to use non-linear stress-strain ratio in reinforced concrete with consideration of specific features of reinforced concrete activity after cracking. Naturally, functional dependence describing this ratio varies along with the progress of rebars corrosion. Exactly, corrosion of rebars is the key reason for time-dependent quality degrading of reinforced concrete structures. This problem stands for more urgency with respect to structures in seismic sensitive zones since such corrosion of rebars leads to deviations of the structure rigidity characteristics and, in turn, it may lead to an reduction of bearing capability in certain elements or to an increase of displacements to intolerable high values. This study proposes a clarified procedure to solve plane-stressed problem for reinforced concrete. The specific feature of this procedure assumes an application of new approximation for non-linear concrete strain diagram, development of a detailed finite element model for reproduction of effect generated under concrete/rebar bond forces, as well as such considerable time-dependent factors as concrete creep and rebar corrosion.
\end{abstract}

Keywords: reinforced concrete, finite element model, non-linear deformation, corrosion of rebars, seismic impact.

\section{Introduction}

Accumulation of damages in reinforced concrete structures during service life, in particular, leads to reduction of cohesion force intensity between concrete and rebars. Corrosion of concrete and rebars is one of major reasons of structural material quality degrading. It is well known in the industry [1], that products of chemical interaction between corrosive medium and concrete gradually fill all pores and grooves in concrete and thus facilitate fracture of protective layer with partial exposure of rebars. Under systematic contacts, seawater exerts noxious effects on concrete. In addition, ground waters also may have corrosive effect. All these phenomena have direct effects on stressed state of structural components.

The most critical specific feature of reviewed problem assumes the necessity to take in consideration nonlinear relation between tangent cohesion forces in rebar/ concrete contact points from one side, and longitudinal displacements (sliding) of rebars relative to concrete, from the other one. Naturally, functional ratios characterising this relationship change along accumulation of defects and, in particular, along an increase of corroded metal mass. Rigorous theoretical description of these processes may be based on physical diffusion laws, however, approximated formulae of empirical origin are often used for practical applications.

In addition, it should be noted that corrosion and other defects associated with environmental effects might drastically influence the long-term material durability [2].

\section{Theoretical premises of finite element calculation}

Experimental and theoretical investigations of bond resistance between reinforcement and concrete were conducted starting the twenties of the last century [3]. Considerable steps forward in the $50 \mathrm{~s}$ were famous works by A. A. Gvozdev [4], V. I. Murashev [5], O. Y. Berg [6].

Various versions of relationships between tangential bond stress and reinforcement slippage against concrete have been proposed: linear law, power law, and law of ideal elasto-plastic strain. By the results of a large number of tests conducted by the Research \& Development Institute of Reinforced Concrete, in $1959 \mathrm{M}$. M. Kholmyanskiy [7] offered so-called "normal law": 


$$
\tau=B_{0} \ln \left(1+\alpha_{0} s\right) /\left(1+\alpha_{0} s\right)
$$

where $\tau$ - tangential bond stress; $s$ - reinforcement shift against concrete; $B_{0}, \alpha_{0}$ - parameters used in bond law dependable upon concrete compression strength and reinforcement diameter.

The results of similar foreign investigations have been reflected in current calculation and design standards, such as DIN 1045-1, Eurocode 2, and CEB-FIP Model Code 90. In particular, in Model Code 90 for heavy concrete bond is determined with analytical expressions given in Fig 1.

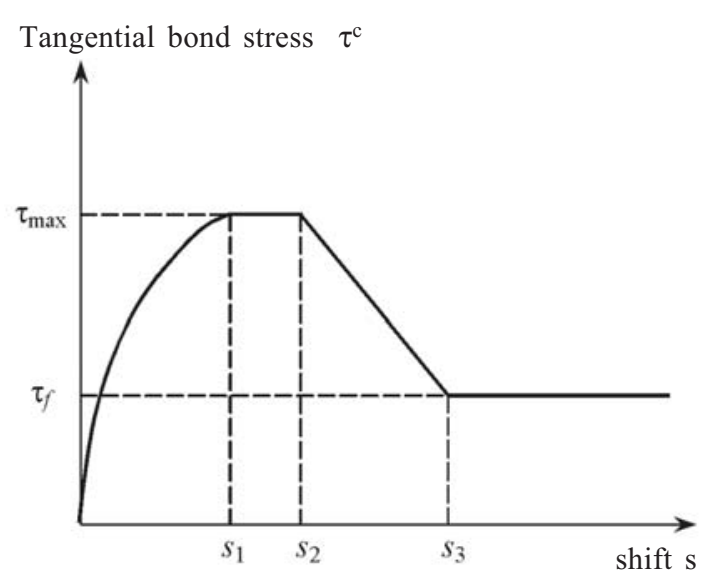

$$
\begin{array}{ll}
\tau=\tau_{\max }\left(s / s_{1}\right)^{\alpha}, & \text { at } 0 \leq s<s_{1} ; \\
\tau=\tau_{\max }, & \text { at } s_{1} \leq s<s_{2} ; \\
\tau=\tau_{\max }+\left(\tau_{f}-\tau_{\max }\right)\left(s-s_{2}\right) /\left(s_{1}-s_{2}\right), & \text { at } s_{2} \leq s<s_{3} ; \\
\tau=\tau_{f}, & \text { at } s \geq s_{3} .
\end{array}
$$

Fig 1. Diagram "shift - tangential bond stress" for noncorroding reinforcement under CEB-FIP Model Code 90

The parameters of this law depend on the concrete strength and bond quality, but are independent of the reinforcement diameter [8].

Some of versions of $\tau-s$ curve in presence of corrosion are shown in Fig 2.

Numerical parameters characterising the above versions, first of all, depend on corrosion penetration into the rod body $x(t), \mathrm{mm}$, which can be calculated using Faraday's law [11]:

$$
x(t)=0,0116\left(t-t_{0}\right) V_{\text {corr }},
$$

where $t$ - current time; $t_{0}$ - time of commencement of corrosion development.

Factual (residual) diameter of the $\operatorname{rod} d_{R}$, which should be taken into account in calculation if equal to:

$$
d_{R}=d_{0}-\alpha x(t)
$$

where $d_{0}$ - initial (rated) diameter.

Factor a can be accepted as equal to 2 under corrosion, which is uniform by the perimeter of the rod's crosssection, and by its length. In case of spot (so-called "pitting") corrosion, the value of a factor is in the range of 4 and 8.
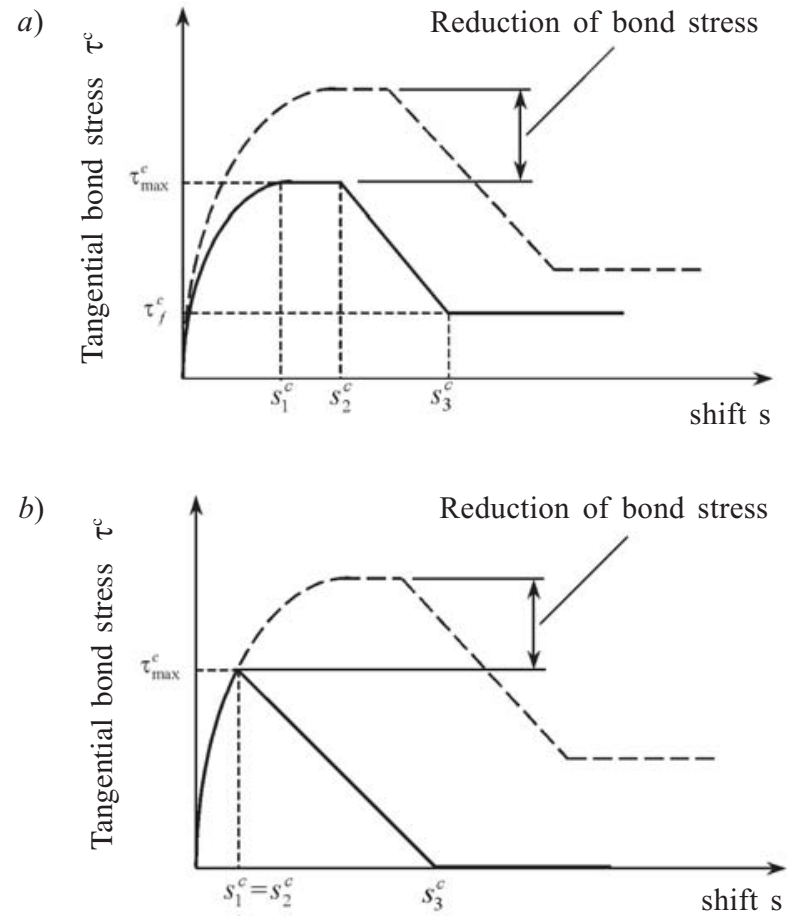

Fig 2. Models "shift - tangential bond stress" for corroding reinforcement: a) Horrigmoe and Torlen [9]; b) Castellani and Coronelli [10]

As a rule, reinforced concrete structures with sufficient thickness of concrete protective layer may be used for a long period without any noticeable corrosion of rebars. However, in certain cases this defect is found to be critical. Paragraph [3] describes a case, when in the course of investigation of two 13-year age arc vaults subjected to fumes of passing locomotives, it was found that in certain points the depth of penetrated corrosion in the body of rebars reached $0,5 \mathrm{~mm}$. Therefore in this case an average corrosion rate was almost $0,04 \mathrm{~mm} /$ year.

The general procedure for the non-linear calculation of reinforced concrete structures for seismic resistance is follows.

\section{Finite element scheme of calculation}

Fig 3 illustrates a typical fragment of the FEM model for a flat reinforced concrete structure. Concrete is simulated with rectangular elements, which borders are shown with thin vertical and horizontal lines. Thick dots indicate the nodes, which a horizontal reinforcement bar passes. In order to make it clearer, the bar axis (black thick line) is shifted on the drawing a little lower than the above-mentioned nodes.

Reinforcement bar nodes and concrete elements nodes, with which the bar is tied, have the same pairwise coordinates, but different numbers. Therefore, concrete nodes and reinforcement nodes in the accepted analytical model, which coincided before the load has been applied, during deformation process may receive the values of mutual displacement other than zero. Thus, the 


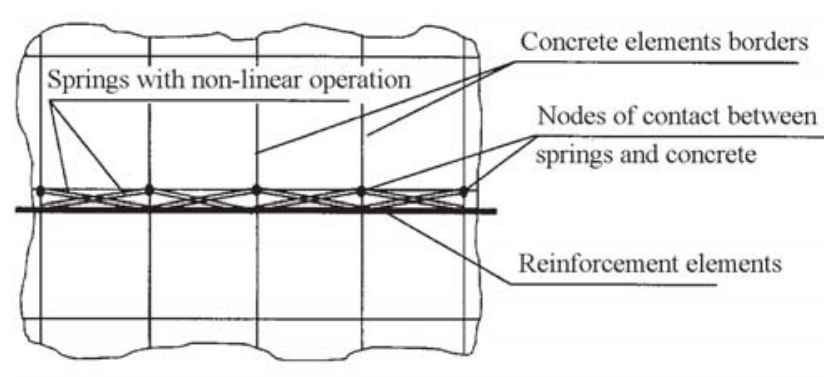

Fig 3. Fragment of FEM model for reinforced concrete structure

process of reinforcement slipping against concrete due to adhesive force action is simulated.

Horizontal springs are the elements, wherein strength equivalent to the adhesive forces occurs. In the drawing, these elements are shown with doubled lines (not horizontal, but slanting lines by reason of the above-mentioned displacement of the bar axis against the actual position of its nodes).

It can be seen that each pair of the nodes initially having the same coordinates is tied with each of the adjacent pairs (from the right and the left) with two springs. In principle, it would be enough to tie each reinforcement node with an appropriate concrete node with one spring. However, the variant accepted in the performed calculations (with two springs in each section) has certain strong points, which become apparent in computer implementation of the computational algorithm. This particular variant provides better mutual tie-up of the FEM model elements having different physical nature, results in a more uniform distribution of adhesion forces obtained in calculation, and is conducive to acceleration of iterative process convergence.

As deflected mode of the system changes, its stiffness characteristics are recalculated. Concrete is considered as a material having acquired anisotropy, with a tie between strains and stresses in the plane of principal strain being described by cubical parabola [12].

Respectively, on each stage, new values of secant modules and coefficients of transverse strain (Poisson's coefficients) are determined for concrete elements.

For reinforcement bars elements, elastic modulus is assumed to be constant until stress in the reinforcement reaches the yield point, and only with strains in the order of 0,002 or higher, secant module is calculated as a ratio between the yield point and attained strain.

On the first stage of calculation, springs simulating the tie between concrete and reinforcement have the initial stiffness, the method of determination of which depends upon the accepted adhesion law. Once the next calculation stage is completed, elongations $s_{1, i}$ and $s_{2, i}$ of two springs are determined for each section using the formulas

$$
s_{1, i}=F_{1, i} / c_{i} ; s_{2, i}=F_{2, i} / c_{i}
$$

where $c_{i}$ - stiffness of springs in section number $i ; F_{1, i}$ and $F_{2, i}$ - forces in two springs in the same section.

Average value of the reinforcement displacement against concrete in section $i$ :

$$
s_{i, a v}=0,5\left(s_{1, i}+s_{2, i}\right) .
$$

Tangential bond stress within the section:

$$
\tau_{i}=\left(F_{1, i}+F_{2, i}\right) /\left(p \cdot d_{i}\right),
$$

where $p$ - perimeter of cross-section of the reinforcement bar; $d_{i}$ - section length.

In accordance with the accepted adhesion law, a new value of the tangential stress $\tau_{i}^{*}<\tau_{i}$ should correspond to displacement $s_{i, a v}$. Then, corrected stiffness of each spring will be equal to:

$$
c_{i}^{*}=0,5 \tau_{i}^{*} \cdot p \cdot d_{i} / s_{i, a v},
$$

(in this formula, factor 0,5 is conditioned by the existence of two springs within the section). Once the stiffness values of all springs are clarified, the next stage of calculation can be started.

Convergence of iteration process has been estimated by comparison of potential energy accumulated in all concrete elements on two sequential calculation steps (fixed relative error being equal to $2 \%$ ).

It is worth noting another feature of the accepted analytical model. It is known that when designing reinforced concrete structures measures should be taken to provide attachment of the reinforcement ends in concrete. For example, for non-prestressed structures, such measures may involve bringing the bars over the limits of effective span to the required length of the anchoring, application of steel meshes and frameworks, arrangement of hooks on the bar ends (in case of application of reinforcement of A-I category). In order to prevent slippage of reinforcement bar ends against concrete in the accepted FEM model, the source data are supplemented with the requirement that horizontal displacements of the appropriate nodes should be the same.

Besides, the condition of compatibility of vertical displacements of all reinforcement bars nodes and corresponding concrete elements nodes should be observed.

Iterative process of clarification of seismic forces may be performed using the algorithm described in [13].

To the first approximation, with initial stiffness characteristics, oscillation periods are determined and, using Construction Rules \& Regulations (SNiP II-7-81* [14]), seismic forces applied to localised masses are found.

Non-linear calculation of a structure for such forces results in obtaining new (reduced as compared with the initial ones) stiffness characteristics of the system. In accordance with them, oscillation periods are clarified (towards increase), which allows obtaining the next approximation of seismic forces. Iterative process is stopped when forces in two consequent approximations become sufficiently close to each other. 


\section{Example of calculation}

Seismic resistance of five-storey bearing-wall building is investigated. Transverse wall of $12 \mathrm{~m}$ width is selected as a specific object for calculation, which by its calculation scheme represents a set of plates with $16 \mathrm{~cm}$ thickness. Ceiling plates are jointed with horizontal surfaces of wall panels via flexible links which mostly act for shear (two rows of rebars $\varnothing 20 \mathrm{~A}-\mathrm{III}$ at $0,40 \mathrm{~m}$ spacing). Material of the wall is of concrete B30 class.

The calculation scheme includes rectangular finite elements of the wall, top and bottom shear links (spring type elements), as well as beam elements simulating the top and the bottom ceiling. Initial value of shear stiffness for one spring is $45 \mathrm{MN} / \mathrm{m}$. Calculation of area and moment of inertia for beam elements is made with consideration of ceiling plates involved in wall action at reference width $1,0 \mathrm{~m}$. It is assumed that the bottom wall panel rests on elastic support with bed factor $50 \mathrm{MN} / \mathrm{m}^{3}$. Initial values of reinforced concrete modulus of elasticity along directions in parallel to rebars is defined as $E_{x}=E_{b 0}\left(1+n_{0} \mu_{x}\right)$ and $E_{y}=E_{b 0}\left(1+n_{0} \mu_{y}\right)$. In this case, the wall panel is reinforced by two rows of rebars $\varnothing 10$ A-III at $0,30 \mathrm{~m}$ spacing both vertically and horizontally. Relevant initial values of reinforcement factor are $\mu_{x}=\mu_{y}=0,00326$. Value $n_{0}$ is $E_{s 0} / E_{b 0}\left(E_{s 0}, E_{b 0}\right.$ are initial modules of steel and concrete).

During successive approximations we took into consideration dependence of concrete mechanical properties with concrete stressed state, pre-set diagram of stress/ strain ratio. Specific points of this diagram: apex with co-ordinates $\left(R, \varepsilon_{R}\right)$ and diagram break point $\left(\sigma_{u l t}, \varepsilon_{u l t}\right)$, where $R$ - concrete ultimate stress for compression or elongation and stress in finite point $\sigma_{u l t}$ may be accepted equal to $[15](0,7 \ldots 0,8) \cdot R$. Modules $E_{x}, E_{y}$ are re-calculated with consideration of reduced concrete rigidity:

$$
E_{x}=E_{b x, s e c}\left(1+n_{x} \mu_{x}\right) ; \quad E_{y}=E_{b y, s e c}\left(1+n_{y} \mu_{y}\right),
$$

where $n_{x}=E_{s} / E_{b x, s e c} ; n_{y}=E_{s} / E_{b y, s e c}$.

Secant modulus $E_{s}$ is defined in accordance with diagram of steel and secant modules $E_{b x, s e c}$ and $E_{b y, s e c}$ are defined by the deformation diagram of concrete.

The above formulae for $E_{x}, E_{y}$ are correct (during elongation) under the condition $\varepsilon<\varepsilon_{R}$ only. During transition over the diagram apex, a process of cracking starts and directions along the crack and by normal to the crack (ie along direction of the main tensile strain $\varepsilon_{1}$ ) must be accepted as orthotropy axes. In this case, characteristics of material rigidity in direction of the above normal are defined by the formula [16]:

$$
E_{\phi}=E_{s} \mu_{\phi} / \psi_{\mathrm{a}}
$$

where $\mu_{\phi}=\mu_{x} \cos ^{4} \phi+\mu_{y} \sin ^{4} \phi$,

Here multiplier $\mu_{\phi}$ reflects the degree of rebar effects in parallel to axes $x$ and $y$, on rigidity by normal to the crack; $\phi$ - angle of normal inclination to axis $x$.

For coefficient $\psi_{\mathrm{a}}$ introduced by V. I. Murashev, we may accept a well-known empirical formula:

$$
\psi_{\mathrm{a}}=1-0,7 R_{t} / \sigma
$$

where $R_{t}$ - concrete tensile strength and the stress is expressed via strain along a normal to the crack $\sigma=E_{\phi} \varepsilon_{\phi}$.

Finally, if strain (both tensile and compression) attains $\varepsilon_{u l t}$ value, concrete is completely deactivated from operation, adhesion forces stop to act within reviewed element and resistance of this element is defined by rebars only, namely $E_{\phi}=E_{s} \mu_{\phi}$.

Calculation was completed with consideration of curve $\tau-s$ for rebars without corrosion at $\tau_{\max }=4 \mathrm{MPa}$, $\tau_{f}=0,6 \mathrm{MPa}, s_{1}=s_{2}=0,6 \mathrm{~mm}, s_{3}=2,5 \mathrm{~mm}$. The wall is estimated for horizontal seismic load using spectral theory [14].

For initial period of building operation (before corrosion process starts), the first period of oscillation is equal to $T_{1}=0,3298 \mathrm{~s}$. With seismic load relevant to this period, horizontal displacement of the building top ceiling is $31,9 \mathrm{~mm}$ with tolerance equal to $1 / 500$ of the building height, ie in this case $32 \mathrm{~mm}$. The result of calculations demonstrates that compression stress is far from ultimate values (ultimate compression stress is 23,8 $\mathrm{MPa}$ ), but in cross-bar, this value attains the limit of tensile stress (ultimate tension stress - 2,05 $\mathrm{MPa}$ ). Therefore rebars actively act in the cross-bar, where stresses exceed $250 \mathrm{MPa}$.

Fig 4 shows fields of principal compression and stretching stresses in the most stressed wall panel, ie the panel of the first story. Concentration of compression stresses in re-entrant angles (in the lower portion of crossbar bearing cross-sections) is evident. The highest stretching stresses originated in the top portion of the same cross-sections, in particular, exactly these areas have launched a process of micro-cracking which finally leads to reduction of elastic modulus in the main directions.

Recalculation of strained and stressed state was made in the process of each successive iteration. As a result, elastic modulus of all components was gradually reduced; however if the load is below maximum tolerances, the process for variation of rigidity characteristics is found to be convergent. An article [13] (for the other struc-

a)

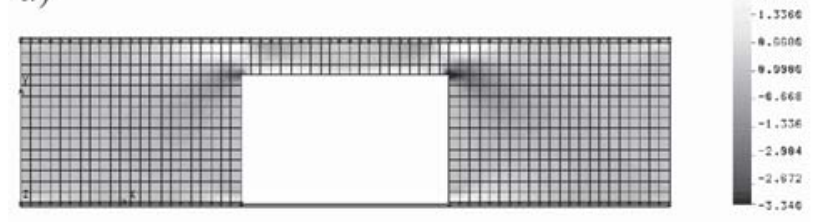

b)

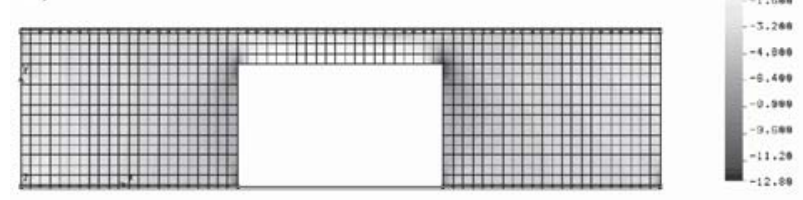

Fig 4. Principal stresses in wall panel, MPa: $a$ - principal compression $\left(\sigma_{3}\right) ; b$ - principal stretching $\left(\sigma_{1}\right)$ 
ture) demonstrates an example of process convergence by estimation of building oscillation frequency, which material rigidity degrades under the influence of seismic forces.

Concrete creepage is also considered by multiplication of initial modulus by factor $\left(1+E_{b 0} C_{b} \xi_{l} \xi_{h}\right)^{-1}$, here: $C_{b}$ - ultimate creepage value; $\xi_{l}, \xi_{h}$ - factors depending on the nature of load and panel thickness. It is accepted $C_{b}=7 \cdot 10^{-5} \mathrm{~m}^{2} / \mathrm{MN}$ and $\xi_{l}=\xi_{h}=1,0$.

To calculate the wall with consideration of adhesion forces with available corrosion, we used a curve $\tau-s$ according to Horrigmoe and Torlen model (Fig 2, a) with modified values of the following parameters: $\tau_{\text {max }}^{\mathrm{c}}=2,4 \mathrm{MPa}, \tau_{f}^{\mathrm{c}}=0,4 \mathrm{MPa},{s^{\mathrm{c}}}_{1}={s^{\mathrm{c}}}_{2}=0,4 \mathrm{~mm}$, $s^{\mathrm{c}}{ }_{3}=1,75 \mathrm{~mm}$. Stiffness of springs modelling shear links will be equal to $31,5 \mathrm{MN} / \mathrm{m}$. The first period of oscillations for loosened structure is increased almost by $30 \%$ $\left(T_{1}=0,4269 \mathrm{~s}\right)$.

Maximum value of main compression stresses is reduced to $10 \mathrm{MPa}$ and stresses in rebars go down almost 1,5 times. At the same time reduction of structural rigidity leads to an increase of displacement. In particular, the ceiling of top storey deflects horizontally by $36 \mathrm{~mm}$ which exceeds tolerance by $12,5 \%$.

\section{Conclusions}

Practical results of completed study may include the following.

1. A simultaneous numerical registration of several factors was completed for specific tasks which become evident in time, such as non-linearity, creep, accumulation of damages (in particular, corrosion of rebars).

2. It is demonstrated that opportunities of modern software complexes in combination with the author's programs may be used for embodiment of such registration that governs recalculation of mechanical material properties in automatic mode.

3. In lieu of today still often used simplified and conditional approaches to analyse reinforced concrete behaviour at design stage, we may propose a new procedure that enables to approach closely and obtain a trustworthy picture of strained and stressed state of structural components.

However, it is necessary to note that complication of calculation and universality for its application bear an actual meaning with the use of trustworthy hypotheses and reliable values of numerical parameters only, which describe the material behaviour.

\section{References}

1. Baikov, V. N.; Sigalov, E. E. Reinforced Concrete Structures: General Course, $2^{\text {nd }}$ ed. Moscow: Stroiizdat, 1977. $783 \mathrm{p}$.

2. Kachanov, L. M. Fundamentals of Destruction Mechanics. Moscow: Nauka, 1974. 312 p.
3. Zaliger, R. Reinforced Concrete, its Calculation and Design - Translated from German, $5^{\text {th }}$ edition. Moscow: GNTI, 1931. $671 \mathrm{p}$.

4. Gvozdev, A. A. Calculation of Load-Carrying Capacity of Structures using Limit Equilibrium Method. Edition 1: Method Essentials and Justification. Moscow: Stroiizdat, 1949. 279 p.

5. Murashev, V. I. Crack-Resistance, Hardness and Strength of Reinforced Concrete (Fundamentals of Reinforced Concrete Resistance). Moscow: Mashstroiizdat, 1950. 267 p.

6. Berg, O. Y. Investigation of Crack Formation in Reinforced Concrete Elements with Reinforcement with Die-rolled Section. Central Research \& Development Institute of the Ministry of Communication Lines. Report No 44. Moscow: Transzheldorizdat, 1954. 23 p.

7. Kholmyanskiy, M. M. Contact of Reinforcement with Concrete. Moscow: Stroiizdat, 1981. 182 p.

8. König, G.; Dehn, F.; Holshemacher, K.; Weiße, D. Determination of the bond creep coefficient for lightweight aggregate concrete (LWAC) under cycle loading. In: Concrete for Extreme Conditions: Proceedings of the International Conference held at the University of Dundee, Scotland, UK on 9-11 Sept 2002. London: Tomas Telford Publishing, 2002, p. 673-683.

9. Torlen, A.; Horrigmoe, G. Modeling of bond between reinforcement and concrete for deteriorated and repaired beams (in Norwegian). NORUT Technology, Narvik, Norway, 1998, Report No NTAS A98034.

10. Castellani, A.; Coronelli, D. Beams with Corroded Reinforcement: Evaluation of the Effects of Cross-section Losses and Bond Deterioration by Finite Element Analysis. Structural Faults and Repair-99, London, UK, July 1999.

11. Horrigmoe, G. Assessment of the Performance and Safety of Deteriorated Concrete Structures. In: Concrete Solutions: Conference Proceedings and Papers $1^{\text {st }}$ Intern Conference on Concrete Repair, St-Malo, France, 15-17 July 2003. Published by GR Technologie Ltd, London, UK, 2003. Vol 1, p. 209-223.

12. Benin, A. V.; Elizarov, S. V.; Tananaiko, O. D. Numerical comparison of various models to describe non-linear behavior of concrete under plane stress. In: XIX Intern Conference "Mathematical simulation in continuum mechanics. Boundary element method and finite-element method". Works, v. II. - SPb, St Petersburg's Scientists House, 2002, p. 76-81.

13. Benin, A. V.; Tananaiko, O. D. On Approximate Account of Linear Strain of the Material Using Spectral Method of Seismic Stability Estimation. Earthquake-proof Construction, Structural Safety, No 2, 2003, p. 31-33.

14. Construction Rules \& Regulations SNiP II-7-81*. Construction in Seismic Hazardous Areas./Gosstroi of Russia. Moscow: 2000. 30 p.

15. Karpenko, N. I. General models of reinforced concrete mechanical properties. Moscow: Stroiizdat, 1996. 416 p.

16. Geniev, G. A.; Kissuk, V. N.; Tyupin, G. A. Theory of concrete and reinforced concrete plasticity. Moscow: Stroiizdat, 1974. $316 \mathrm{p}$. 


\section{BETONO IR ARMATŪROS SUKIBIMO İVETINIMAS SKAIČIUOJANT GELŽBETONINIŲ ELEMENTŲ ATSPARUMĄ SEISMINĖMS APKROVOMS}

\section{A. V. Benin}

\section{Santrauka}

Apžvelgtas alternatyvus gelžbetoninių baigtinių elementų modelis, kuriame atskirai ịvertintos kiekvieno sistemos elemento fizikinès sąlygos ir papildomai atsižvelgta ì sistemos elementų tarpusavio sąveiką. Tokiu atveju atsiranda galimybė įvertinti specifines armatūros savybes, stebėti apkrovimo istoriją ir kiekvieno strypo irimą. Sprendžiant aprašytą problemą reikia ịvertinti netiesini gelžbetonio ịtempių-deformacijų būvị, atsiradus plyšiams elemente. Be abejo, šiam būviui aprašyti taikoma funkcija priklauso nuo strypų korozijos lygio. Būtent strypų korozija yra pagrindinis veiksnys, lemiantis gelžbetoninių elementų degradaciją laikui bėgant. Ši problema ypač aktuali konstrukcijas eksploatuojant seisminėse zonose, kadangi strypų korozija mažina elemento standumą, o tai savo ruožtu sukelia jo laikomosios galios sumažejimą arba ilinkių didejjimą iki neleistinų reikšmių. Pateikta aprašytos problemos sprendimo metodika, kuri taikoma gelžbetoninių elementų plokščiojo įtempių būvio atveju. Pagal šią metodiką taikoma nauja netiesinès betono įtempių-deformacijų diagramos aproksimacija, sukurtas detalus baigtinių elementų modelis betono ir armatūros sukibimui įvertinti, atsižvelgta i laikui bejgant atsirandančius efektus, tokius kaip betono valkšnumas ir armatūros korozija.

Raktažodžiai: gelžbetonis, baigtinių elementų modelis, netiesinès deformacijos, strypų korozija, seisminis smūgis.

Andrey V. BENIN. Head of the Mechanical laboratory named after Prof N. A. Beleljubsky of St Petersburg State Transport University, Russia. Assistant professor at the Materials and Structures Strength Studies Dept. Area of research interests: deformed solid-state mechanics, mechanics of destruction, the behaviour of reinforced concrete structural elements, particularly dealing with aseismic construction problems. 